\title{
Application of water quality index to assess suitability of groundwater quality for drinking purposes in Ratmao -Pathri Rao watershed, Haridwar District, India
}

\author{
Mufid al-hadithi \\ Assistant professor, Institute of Technical, Anbar, Iraq
}

\begin{abstract}
Water Quality Index has been applying in the present study to assess suitability of groundwater quality for drinking purposes in Ratmao -Pathri Rao Watershed, Haridwar District, India. This was carried out by subjecting twenty one groundwater samples, collected from eleven selected site, to comprehensive physico-chemical analysis. Nine parameters have been considered for calculating the WQI such as: $\mathrm{pH}$, total hardness, calcium, magnesium, bicarbonate, chloride, nitrate, sulphate, and total dissolved solids. The computed WQI shows that $48 \%$ of water sample falls in excellent categories and $48 \%$ falls in the good water category. On the other hand one site located at Teliwala village which represent $4 \%$ falls in very poor categories. Such waters are not suitable for drinking purposes under normal condition and further action for salinity control is required. The high value of WQI at this site has been found to be mainly due to the higher values of TDS, $\mathrm{Ca}^{+2}$, $\mathrm{K}^{+}, \mathrm{Cl}^{-}, \mathrm{HcO}_{3}{ }^{-}, \mathrm{No}_{3}{ }^{2-}$ and $\mathrm{So}_{4}{ }^{2-}$ where it was found that there is a very high correlation coefficient between them
\end{abstract}

Key words: Water quality Index, Drinking, Ratmao- Pathri Rao watershed, India

\section{INTRODUCTION}

According to World Health Organization, about $80 \%$ of all the diseases in human beings are caused by water. Once the groundwater is contaminated, its quality cannot be restored by stopping the pollutants from the source therefore it becomes very important to regularly monitor the quality of groundwater and to device ways and means to protect it. WQI, a technique of rating water quality, is an effective tool to assess spatial and temporal changes in ground water quality and communicate information on the quality of water to the concerned citizens and policy makers (Mishra and Patel, 2001) (Tiwari and Mishra, 1985). WQI is defined as a rating reflecting the composite influence of different water quality parameters, which is calculated from the point of view of the suitability of groundwater for human consumption. WQI has been successfully applied to asses the quality of groundwater in the recent years due to its serves the understanding of water quality issues by integrating complex data and generating a score that describes water quality status. Horton (1965) has firstly use the concept of WQI then developed by Brown et.al. (1970) and improved by Deininger (Scottish development department, 1975). The development of WQI for groundwater is described in the several studies (Backman et al. (1998), Soltan (1999), Stigter et al. (2006a, b), Saeedi et al. (2009), Ramakrishnalah et al. (2009), khaleed, 2010 and (Rizwan and Singh, 2010).

The objective of the present work is to apply WQI to assess suitability of groundwater for drinking proposes in Ratmao -Pathri Rao Watershed; Haridwar District, India. The study area is located between latitudes $29^{\circ} 50^{\prime} 00^{\prime \prime}$ to $30^{\circ} 11^{\prime}{ }^{\prime} 21^{\prime \prime}$ North and Longitude $77^{\circ} 54^{\prime} 19^{\prime \prime}$ to $78^{\circ} 06^{\prime} 21^{\prime \prime}$, covering an area of approximately $430 \mathrm{~km}^{2}$ (Fig.1).

\section{MATERIALS AND METHODOLOGY}

Groundwater samples were collected from 21 locations during post-monsoon period (April 2003). Each of the groundwater samples was analyzed for 12 parameters such as $\mathrm{pH}$, TDS, total hardness, bicarbonate, chloride, sulphate, nitrate, calcium, magnesium, sodium and potassium using standard procedures recommended by APHA (1998). Details of sampling locations along with their latitude and longitude are presented in Table 1. The location of the collected sample were selected on the basis of hydrgeological unit and different land use pattern .The ground water samples were collected in acid 
washed plastic container to avoid unpredictable changes in characteristic as per standard procedures APHA (1998). The standards for drinking purposes as recommended by WHO (1993) and IS 10500 (Indian Standard, 1992) have been considered for the calculation of WQI. There are three steps for computing WQI:

- According to the relative importance of the chemical parameters in the overall quality of water for drinking purposes specific weights are assigned to them as indicated in table 2 . The most significant parameters have a weight of 5 and the least significant a weight of 1 . Nitrate playing a prominent role in ground water quality for drinking purposes (Ramakrishnalah et al., 2009), thus maximum weight of 5 has been assigned to this parameter whereas the magnesium is not harmful to ground water quality for drinking purposes and the weight of 1 is given to the magnesium (table1).

- Compute the relative weight $\left(\boldsymbol{W}_{i}\right)$ by using the following equation:

$$
\mathrm{w}_{\mathrm{i}}=\frac{\mathrm{w}_{\mathbf{i}}}{\sum^{\mathrm{n}} \mathrm{w}_{\mathrm{i}}}
$$

Where, $\boldsymbol{W}_{\boldsymbol{i}}$ is the relätive weight, $\boldsymbol{w}_{\boldsymbol{i}}$ is the weight of each parameter and $\mathrm{n}$ is the number of parameters.
Calculated relative weight $\left(\boldsymbol{W}_{\boldsymbol{i}}\right)$ values of each parameter are also given in table 2 .

- Calculate a quality rating scale (qi) for each parameter which is assigned by dividing its concentration in each water sample by its respective standard.

- According to the guidelines laid down in the BIS and the result multiplied by 100 .

$$
q i=(\mathrm{Ci} / \mathrm{Si}) * 100
$$

Where $\boldsymbol{q}_{\boldsymbol{i}}$ is the quality rating, $\boldsymbol{C}_{\boldsymbol{i}}$ is the concentration of each chemical parameter in each water sample in $\mathrm{mg} / \mathrm{L}$, and $\boldsymbol{S}_{\boldsymbol{i}}$ is the Indian drinking water standard for each chemical parameter in $\mathrm{mg} / \mathrm{L}$ according to the guidelines of the BIS 10500, 1991.

- Determined $S I_{i}$ for each chemical parameter which has been calculated from the following equation

$$
S I_{i}=W_{i} \cdot q_{i}
$$

- Finally, compute WQI for each chemical parameter by using the following formula:

$$
W Q I=\sum S I_{i}
$$

The computed WQI values are classified into five types, "excellent water" to "water, unsuitable for drinking" (table 3).

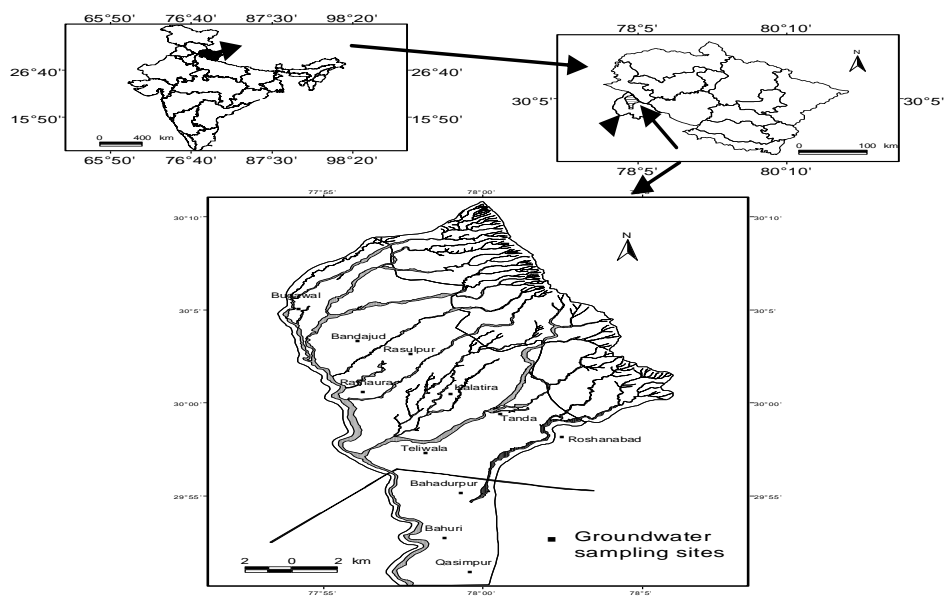

Fig.1: Location map of the study area showing groundwater sampling sites 
Table 1: Sampling location with their latitude and longitude

\begin{tabular}{|c|c|c|c|}
\hline S.No. & Location & Latitude & Longitude \\
\hline GW1 & Rasulpur Village (Deep, open well) & 3002.369 & 7758.021 \\
\hline GW2 & Rasulpur Village (Shallow, open well) & 3002.540 & 7758.390 \\
\hline GW3 & Rathura Village (Deep, open well) & 3000.548 & 7756.480 \\
\hline GW4 & Rathura Village (Shallow, open well) & 3000.256 & 7756.166 \\
\hline GW5 & Banderjood Village (Deep, open well) & 3003.954 & 7754.930 \\
\hline GW6 & Banderjood Village (Shallow, open well) & 3003.456 & 7754.876 \\
\hline GW7 & Bahaderpur Village (Deep, open well) & 2955.357 & 7800.026 \\
\hline GW8 & Bahaderpur Village (Shallow, open well) & 2955.357 & 7800.026 \\
\hline GW9 & Tanda Village (Deep, open well) & 3001.641 & 7758.102 \\
\hline GW10 & Tanda Village (Shallow, open well) & 3001.641 & 7758.102 \\
\hline GW11 & Bahori Village (Deep, open well) & 2953.617 & 7758.900 \\
\hline GW12 & Bahori Village (Shallow, open well) & 2952.248 & 7758.890 \\
\hline GW13 & Teliwala Village (Deep, open well) & 2957.478 & 7758.792 \\
\hline GW14 & Teliwala Village (Shallow, open well) & 2957.567 & 7758.304 \\
\hline GW15 & Qasimpur Village (Deep, open well) & 2950.988 & 7759.190 \\
\hline GW16 & Qasimpur Village (Shallow, open well) & 2951.001 & 7759.100 \\
\hline GW17 & Buggawala Village (Deep, open well) & 3005.754 & 7754.730 \\
\hline GW18 & Buggawala Village (Shallow, open well) & 3005.954 & 7754.930 \\
\hline GW19 & Kalitera Village (Deep, open well) & 3000.986 & 7759.023 \\
\hline GW20 & Kalitera Village (Deep, open well) & 3000.986 & 7759.023 \\
\hline GW21 & Roshanabad Village (Deep, open well) & 2958.143 & 7802.201 \\
\hline
\end{tabular}

\section{RESULT AND DISCUSSION}

Statistical analysis: Statistical analysis was carried out using statistical package for social sciences (SPSS Version13). The statistical tests applied were basic statistics (mean, standard deviation) and Spearman's correlation matrix (assuming $p<0.01$ ). The mean and standard deviations is calculated (table 4) to know the chemical parameters which are deviating from Indian standard for drinking water standard. It has been observed that mean, median and standard deviation for all parameters are within the limits of Indian standard for drinking water.

The degree of a linear association between any two of the water quality parameters, and water quality parameters with WQI as measured by the simple correlation coefficient $(r)$ is presented in Table 5. Correlation analysis measures the closeness of the relationship between chosen variables. If the correlation coefficient is nearer to +1 or -1 , it shows the perfect linear relationship between the two variables. This way analysis attempts to establish the nature of the relationship between the water quality parameters and WQI. It is observed that the TDS variations are mainly controlled by calcium $(r=0.9)$, Sodium ( $r=0.89)$, Potassium $(r=0.69)$, Nitrite $(0.85)$, Sulphate $(r=0.92)$ and Chloride $(r=0.96)$ concentration. In some site the relationship between $\mathrm{Mg}$ and $\mathrm{Cl}$ is highly significant indicates that the hardness of the water is permanent in nature. Computed WQI also show that the highly significant interrelated with the values of TDS $(r=0.93) \mathrm{Ca}(r=$ $0.9), \mathrm{K}(r=0.85), \mathrm{NO}_{3}(0.97), \mathrm{SO}_{4}(r=0.85) \mathrm{Cl}(\mathrm{r}=$ $0.93)$ 
Am. J. Sci. Ind. Res., 2012, 3(6): 395-402

Table 2: Relative weight for each parameter (Ramakrishnalah et al, 2009)

\begin{tabular}{|c|c|c|c|}
\hline Chemical parameters & Si & Weight (wi) & Relative weight (Wi) \\
\hline$p H$ & 8.5 & 4 & 0.121 \\
\hline Total hardness (TH) & 300 & 2 & 0.061 \\
\hline $\mathrm{Ca}^{+}$ & 75 & 2 & 0.061 \\
\hline$M g^{+2}$ & 30 & 2 & 0.061 \\
\hline $\mathrm{Na}^{+}$ & 200 & 2 & 0.061 \\
\hline$K$ & 12 & 2 & 0.061 \\
\hline $\mathrm{HCO}_{3}$ & 250 & 3 & 0.091 \\
\hline $\mathrm{Cl}$ & 250 & 3 & 0.091 \\
\hline TDS & 500 & 4 & 0.121 \\
\hline $\mathrm{No}_{3}$ & 45 & 5 & 0.152 \\
\hline $\mathrm{SO}_{4}$ & 200 & 4 & 0.121 \\
\hline Total & & $\sum w i=33$ & $\sum W i=1$ \\
\hline
\end{tabular}

Table.3: Water quality classification based on WQI value

\begin{tabular}{|l|l|l|l|}
\hline WQI value & Class & Water quality & Percentage of studied water sample \\
\hline$<50$ & I & Excellent & $48 \%$ \\
\hline $50-100$ & II & good water & $48 \%$ \\
\hline $100-200$ & III & poor water & --- \\
\hline $200-300$ & IV & very poor water & $4 \%$ \\
\hline$>300$ & V & Unsuitable water & --- \\
\hline
\end{tabular}

Table 4: Descriptive statistics for all wells

\begin{tabular}{llllllllllll}
\hline & $\mathbf{p H}$ & $\mathbf{T H}$ & $\mathbf{C a}$ & $\mathbf{M g}$ & $\mathbf{N a}$ & $\boldsymbol{K}$ & $\mathbf{H C O}_{3}$ & $\mathbf{C l}$ & $\mathbf{T D S}$ & $\mathbf{N o}_{3}$ & $\mathbf{S o}_{4}$ \\
\hline Mean & 8.7 & 21.1 & 55.9 & 20.9 & 21.5 & 9.8 & 159.4 & 32.9 & 410.7 & 43.6 & 92.7 \\
Median & 8.7 & 21.8 & 47.1 & 18.8 & 13.5 & 2.9 & 149.5 & 12.5 & 339.0 & 19.2 & 67.9 \\
Std. Deviation & 0.4 & 11.1 & 28.7 & 9.6 & 19.4 & 19.2 & 52.6 & 52.5 & 243.9 & 71.1 & 65.7 \\
Minimum & 8.2 & 5.0 & 25.0 & 8.5 & 4.4 & 1.1 & 94.6 & 3.8 & 227.0 & 5.5 & 43.2 \\
Maximum & 9.4 & 41.3 & 137.2 & 38.9 & 86.9 & 78.5 & 280.6 & 231.2 & 1320.0 & 331.0 & 316.9 \\
Indian St. & 8.5 & 300 & 75 & 30 & 200 & 12 & 250 & 250 & 500 & 45 & 200 \\
\hline
\end{tabular}

Table 5: Correlation coefficient matrix of water quality parameters and WQI

\begin{tabular}{|c|c|c|c|c|c|c|c|c|c|c|c|c|}
\hline $\begin{array}{l}\text { Para- } \\
\text { Meters }\end{array}$ & $p H$ & $T H$ & $\mathrm{Ca}$ & $M g$ & $\mathrm{Na}$ & $K$ & $\mathrm{HCO}$ & $\mathrm{Cl}$ & $T D S$ & No3 & So4 & WQI \\
\hline$p H$ & 1 & & & & & & & & & & & \\
\hline$T H$ & 0.30 & 1 & & & & & & & & & & \\
\hline $\mathrm{Ca}$ & -0.49 & -0.12 & 1 & & & & & & & & & \\
\hline$M g$ & -0.22 & -0.19 & 0.32 & 1 & & & & & & & & \\
\hline $\mathrm{Na}$ & -0.25 & -0.01 & 0.68 & 0.67 & 1 & & & & & & & \\
\hline$K$ & -0.15 & 0.25 & 0.45 & 0.17 & 0.59 & 1 & & & & & & \\
\hline $\mathrm{HCO}_{3}$ & -0.11 & -0.38 & -0.01 & 0.64 & 0.19 & -0.34 & 1 & & & & & \\
\hline $\mathrm{Cl}$ & -0.37 & 0.14 & 0.87 & 0.39 & 0.81 & 0.71 & -0.19 & 1 & & & & \\
\hline TDS & -0.40 & 0.00 & 0.90 & 0.54 & 0.89 & 0.69 & 0.02 & 0.96 & 1 & & & \\
\hline $\mathrm{NO}_{3}$ & -0.25 & 0.14 & 0.70 & 0.31 & 0.65 & 0.82 & -0.31 & 0.87 & 0.85 & 1 & & \\
\hline $\mathrm{SO}_{4}$ & -0.43 & 0.06 & 0.87 & 0.39 & 0.78 & 0.57 & -0.15 & 0.96 & 0.92 & 0.78 & 1 & \\
\hline WQI & -0.31 & 0.12 & 0.77 & 0.42 & 0.78 & 0.85 & -0.19 & 0.93 & 0.93 & 0.97 & 0.85 & 1 \\
\hline
\end{tabular}


Total dissolved solids (TDS), $\mathrm{pH}$ and Total hardness: The total dissolved solids in all the study area varies from 227 to $1320 \mathrm{mg} / \mathrm{l}$ (Table 1 \& Fig. 2). The mean concentration of TDS was less than desired limit of $500 \mathrm{mg} / \mathrm{L}$ with a maximum value as high as $1320 \mathrm{mg} / \mathrm{L}$ at Telliwala village due to dense residential area and due to intensive irrigation. The higher values of total dissolved solids are attributed to application of agricultural fertilizer contributing the higher concentration of ions in to the groundwater (Rao, 1986). High values of TDS in groundwater are generally not harmful to human beings but high concentration of these may affect persons, who are suffering from kidney and heart diseases (Gupta, et al, 2004). Water containing high solids may cause also laxative or constipation effects (Kumaraswamy and Pollut Res, 1999).
The Hydrogen-ion concentration $(p H)$ values are one of the important factors of ground water. The mean value of $\mathrm{pH}$ was lower than the desired limit (8.5) prescribed by BIS In some places $\mathrm{pH}$ values outside of the desirable ranges indicating alkaline nature of groundwater. Total hardness of water is a measure of dissolved $\mathrm{Ca}$ and $\mathrm{Mg}$ water expressed as (CaCO3) (Mitra et al. 2007).

According to the grading standards of total hardness $(\boldsymbol{T H})$, groundwater can be divided into soft water $(\mathrm{TH}<150 \mathrm{mg} / \mathrm{L})$, moderately hard water $(150<\mathrm{TH}<300 \mathrm{mg} / \mathrm{L})$, hard water $\mathrm{TH}>300$ extremely hard water $\mathrm{TH}>450 \mathrm{mg} / \mathrm{l}$ water. Total hardness $(\mathrm{TH})$ values range from 5 to $41 \mathrm{mg} / \mathrm{L}$ where a mean and a standard deviation were measured as 21.1 and 11.1 $\mathrm{mg} / \mathrm{L}$ respectively (Table.2). Accordingly, the groundwater quality in study area is general classify as soft water

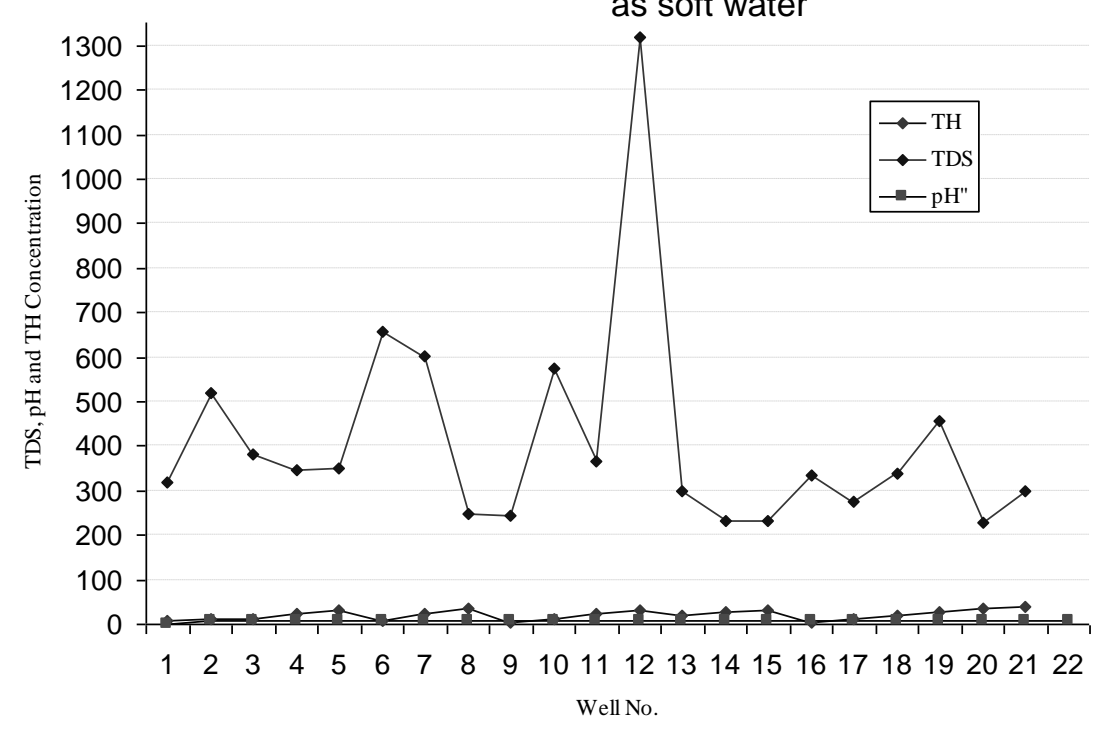

Fig.2: Values of TDS, $\mathrm{pH}$ and TH for all studied sample

Cations Concentration: Calcium can be found in water as $\mathrm{Ca}$ ions therefore it is a determinant of water hardness. The ranges of $\mathrm{Ca}^{+2}$, is 25 to $137 \mathrm{mg} / \mathrm{L}$ as shown in figure (4). All samples were within maximum permissible limit. Low concentration of calcium ion is observed in Well (15) north of the study area due to its location nearby spring line; therefore dilution may occur.

The values of magnesium vary from 8.5 to $38.9 \mathrm{mg} / \mathrm{l}$ (Fig.4). All samples within the maximium permissible limit. In general the source of magnesium in groundwater is the minerals containing magnesium; it is washed from rocks and subsequently ends up in water. Magnesium has many different purposes and consequently may end up in water in many different ways (Deshpande and Aher, 2012). Chemical industries add magnesium to plastics and other materials as a fire protection measure or as filler. It also ends up in the environment from fertilizer application and from cattle feed. In the study area the rock type is indurate to compacted clastic sediments hence the source of magnesium in the groundwater is clay.

All groundwater contains some sodium because most rocks and soils contain sodium compounds from which sodium is easily dissolved. The increasing pollution of groundwater has resulted in a substantial increase in the sodium content of drinking water. According to the (WHO, 1993) and U.S.A. standards 
(cf. Davis and de west, 1966) the water used for drinking purposes should not contain sodium in amount exceeding $200 \mathrm{ppm}$. Accordingly, 100\% of the studied samples are suitable for drinking (fig.5).

The European Economic Community (EEC) has prescribed the guideline level of potassium at 10 $\mathrm{mg} / \mathrm{l}$ in drinking water. As per European Economic
Community (EEC) criteria, 30\% samples exceeding maximum permissible limit while $70 \%$ samples of the study area fall within the guideline level of $10 \mathrm{mg} / \mathrm{l}$. Though potassium is extensively found in some of igneous and sedimentary rocks, its concentration in natural waters is usually quite low. This is due to the fact that potassium minerals offer resistance to weathering and dissolution.

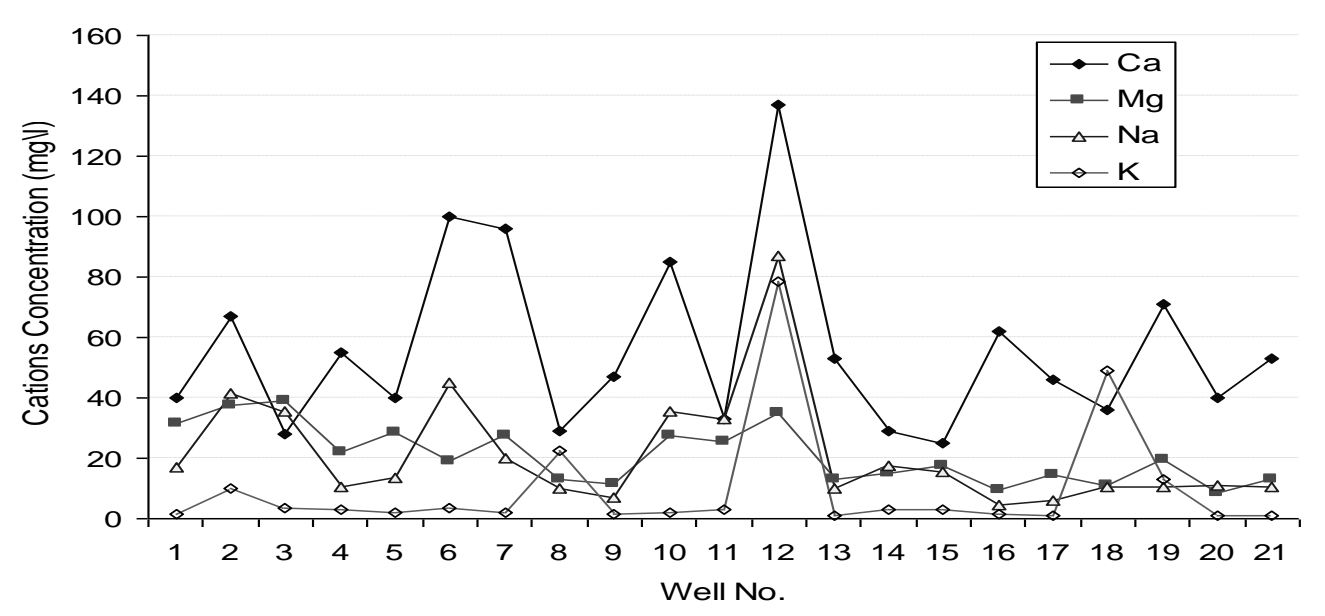

Fig.3: Values of Cations for all studied samples

Anions concentration: The concentration of Bicarbonate in the studied samples ranges between 94.6 and $280.6 \mathrm{mgVl}$ as shown in fig 6. Accordingly, all of these samples are suitable for drinking uses.

The chloride content was found to be well within the permissible limits. It is a widely distributed element in all types of rocks in one or the other form. Therefore, it is high in ground waters, where the temperature is high and rainfall is less (Ramakrishnalah, et al, 2009). Soil porosity and permeability also has a key role in building up the chlorides concentration (Chanda, 1999).

The nitrate value varies from 0.4 to $261 \mathrm{mg} / \mathrm{l}$ in the study area, as shown in fig. 8 The nitrate value for the study area is found to be more than $45 \mathrm{mg} / \mathrm{l}$ as per (WHO, 1993) in three location due to overapplication of fertilizer from agricultural land..

Water Quality Index (WQI): The computed WQI values for 21 wells in Ratmao- Pathri Rao watershed ranges from 37 to 240 as shown in fig.5 and therefore, can be categorized into four types "excellent water" to "very poor water ". Table 4 shows the percentage of water samples that falls under different quality. Accordingly $48 \%$ of wells water falls in class (I) (excellent water) and $48 \%$ falls in class (II) (good water). On the other hand only one site at Telliwala village exceeds (100) the upper limit for drinking water which represent (4\%) of the wells have class (III) (very poor water).

The reason of increasing WQI is considered this region as a drainage system for a groundwater from north east toward south west. In this part, the groundwater quality may improve due to inflow of freshwater of good quality during rainy season. The high value of WQI at this station has been found to be mainly due to the higher values of TDS, $\mathrm{Ca}^{+2}, \mathrm{~K}^{+}$, $\mathrm{Cl}^{-}, \mathrm{HcO}_{3}{ }^{-}, \mathrm{No}_{3}{ }^{2-}$ and $\mathrm{So}_{4}{ }^{2-}$ where it was found that there is a very high correlation coefficient between them 


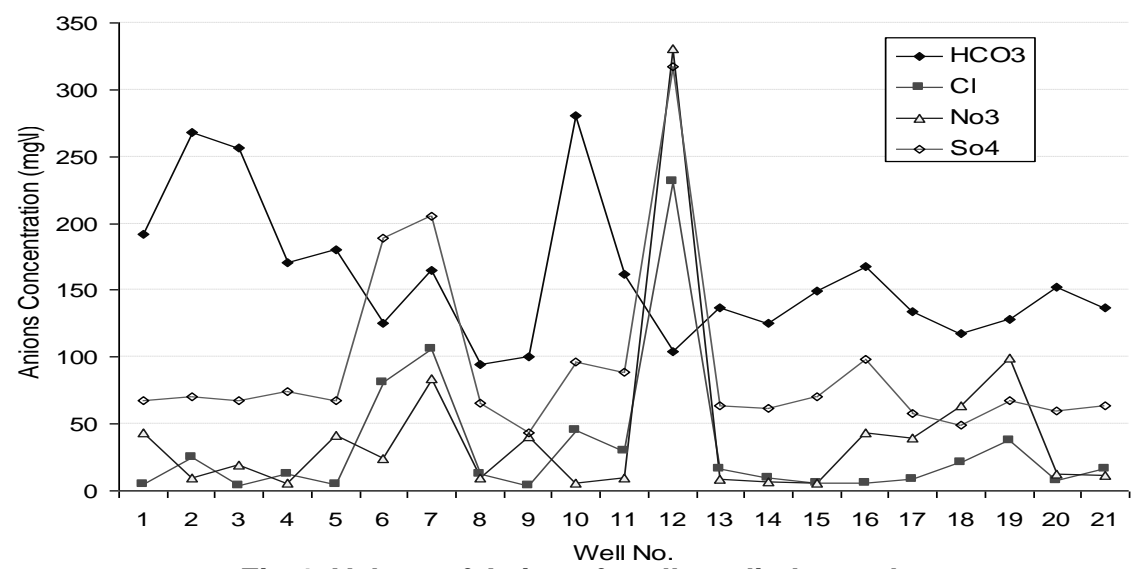

Fig.4: Values of Anions for all studied samples

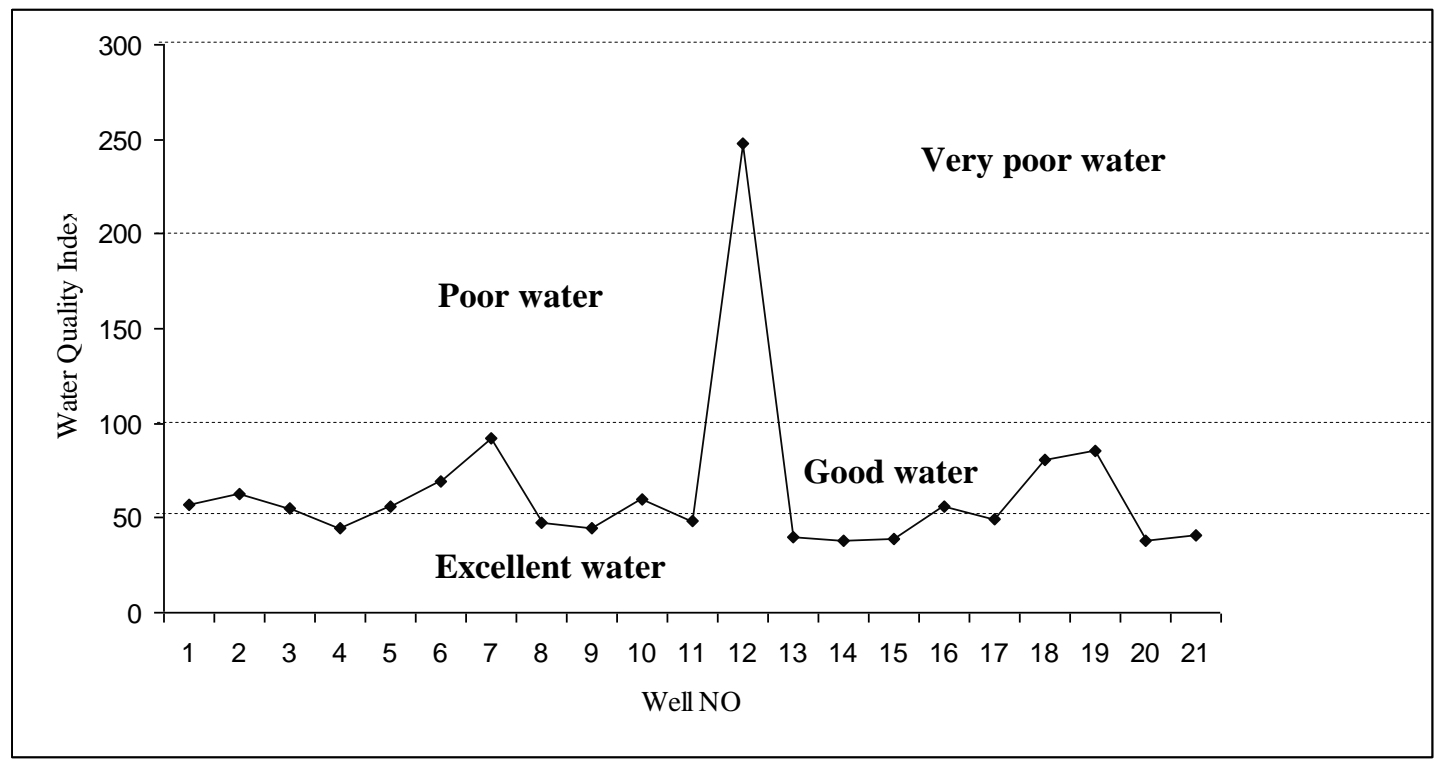

Fig.5: Values of WQI for all studied samples

\section{CONCLUSION}

In the present study water quality index has been computed to assess suitability of groundwater quality for drinking purposes in Ratmao -Pathri Rao Watershed, Haridwar District, India. Twenty one groundwater samples were collected from eleven selected site, to comprehensive physico-chemical analysis. For calculating the WQI nine parameters have been considered such as: $\mathrm{pH}$, total hardness, calcium, magnesium, bicarbonate, chloride, nitrate, sulphate, and total dissolved solids. The result shows that $48 \%$ of water sample falls in excellent categories and $48 \%$ falls in the good water category. Only one site at Tellwala village the WQI exceeded the upper limit for drinking water. It represents four percent of the studied samples laying in fourth class of WQI (very poor water). The high value of WQI at this site has been found to be mainly from the higher values of calcium, potassium, nitrate, total dissolved solids, bicarbonate, and chloride in the groundwater

\section{REFERENCE}

American Public Health Association (APHA), (1998). Standard method for the examination of water and waste water (20 edition) Washington D.C. 
Backman, B., Bodis, D., Lahermo, P., Rapant, S., \& Tarvainen, T. (1998). "Application of a groundwater contamination index in Finland and Slovakia". Environmental Geology, 36(1-2),55-64. DOI: $10.1007 / \mathrm{s} 002540050320$

BIS (Bureau of Indian Standards) 10500, 1991. Indian standard drinking water- specification, First revision, pp 1-8.

Bordalo, A.A., W. Nilsumranchit and K. Chalermwat, 2001. Water quality and uses of the Bangpakong river (Eastern Thailand). Water Res., 35(15): 3635-3642.

Brown, R. M., McClelland, N. I., Deininger, R. A., \& Tozer, R. G. 1970. "A water quality index: Do we dare?" Water \& Sewage Works, 117, 339-343.

Chanda, D.K (1999). A proposed new diagram for geochemical classification of natural waters and interpretation of chemical data, Hydrology J, 7(5): 431439.

Deshpande S.M. and Aher K.R. 2012. Evaluation of Groundwater Quality and its Suitability for Drinking and Agriculture use in Parts of Vaijapur, District Aurangabad, MS, India ,Research Journal of Chemical Sciences , 2(1): 25-31.

Davis, S. N. and De wiest, R.J.M., 1966. Hydrogeology. John Wiley and Sons, New York, 463p

Gupta S, Kumar A, Ojha C.K and Singh G.J, 2004. Environmental Science and Engineering. 46(1): 74-78.

Harilal C C, Hashim A, Arun P R and Baji S, 2004. J Ecology, Environment and Conservation. 10(2): 187192.

Horton, R. K. 1965. An index number system for rating water quality. Journal-Water Pollution Control Federation. 37: 300-305.

Indian Standard (IS: 10500), (1992). Drinking Water Specification (Reaffirmed 1993).

Khalid, H.L (2011). Evaluation of Groundwater Quality for Drinking Purpose for Tikrit and Samarra Cities using Water Quality Index, European journal of scientific research.58 (4):472-481.

Kumaraswamy N, J1999. Pollute Research. 10(1):13-20. .

Mishra, P.C. and R.K. Patel, (2001). Study of the pollution load in the drinking water of Rairangpur, a small tribal dominated town of North Orissa. Indian J. Environment and Ecoplanning.5 (2):293-298.

Mitra B.K., Sasaki C., Enari K. and Matsuyama N., 2007. Suitability assessment of shallow groundwater for irrigation in Sand Dune area of Northwest Honshu
Island, Japan. International Journal of Agricultural Reser ch: 2(6). 518-527.

Mitra, B.K. (1998). Spatial and Temporal Variation of Ground Water Quality in Sand Dune Area of Aomori Prefecture in Japan.

Purandara B K, Varadarajan N and Jayashree K (2003). Pollute Research. 22(2):189.

Ramakrishnalah, C.R; Sadas hivalah C. and Ranganna G, 2009. Assessment of water quality index for the groundwater in Tumkur Taluk, Karnataka state , India, E Journal of chemistry, 6(2), pp.523-530.

Rao N.S. (1986). Hydrogeology and hydrogeochemistry of Visakhapatanam Ph.D Thesis unpublished.

Rizwan R., and Gurdeep S. (2010). Assessment of Ground Water Quality Status by Using Water Quality Index Method in Orissa, India, World Applied Sciences Journal. 9 (12): 1392-1397.

Saeedi M, Abessi O, Sharifi F. and Meraji h. (2009). Development of groundwater quality index. DOI: 10.1007/s: 10661-009-0837-5.

Scottish Development Department (1975). Towards cleaner water. Edinburgh: HMSO, Report of a River Pollution Survey of Scotland.

Soltan, M. E. (1999). Evaluation of groundwater quality in Dakhla Oasis (Egyptian Western Desert). Environmental Monitoring and Assessment. 57(2): 157-168. DOI: 10.1023/a: 10059-489-3031-6

Stambuk-Giljanovic, N. (1999). Water quality evaluation by index in Dalmatia. Water Res.33(16): 3423-3440.

Stigter, T. Y., Ribeiro, L., \& Carvalho Dill, A. M. M. (2006a). Application of a groundwater quality index as an assessment and communication tool in agroenvironmental policies-Two Portuguese case studies. Journal of Hydrology (Amsterdam). (327): 578-591.

Stigter, T. Y., Ribeiro, L., \& Carvalho Dill, A. M. M. (2006b). Evaluation of an intrinsic and a specific vulnerability assessment method in comparison with groundwater salinisation and nitrate contamination levels in two agricultural regions in the south of Portugal, Journal of Hydrogeology.14(1-2): 79-99.

Tiwari, T.N. and M.A. Mishra, 1985. A preliminary assignment of water quality index of major Indian rivers. Indian J. Environmental Protection.5: 276-279.

WHO, (1993). Guidelines for drinking water quality $\left(2^{\text {nd }}\right.$ Ed., Vol. 1, pp. 188). Recommendations, Genev and World Health Organization. 